\title{
Synthesis of unsymmetrically substituted biaryls via sequential lithiation of dibromobiaryls using integrated microflow systems
}

\author{
Aiichiro Nagaki, Naofumi Takabayashi, Yutaka Tomida
}

and Jun-ichi Yoshida*

Open Access

\author{
Full Research Paper \\ Address: \\ Department of Synthetic Chemistry and Biological Chemistry, \\ Graduate School of Engineering, Kyoto University, \\ Kyotodaigakukatsura, Nishikyo-ku, Kyoto, 615-8510, Japan \\ Email: \\ Jun-ichi Yoshida* - yoshida@sbchem.kyoto-u.ac.jp \\ * Corresponding author \\ Keywords: \\ dibromobiaryls; fast mixing; integrated microflow system; selective \\ lithiation; unsymmetrically substituted biaryls
}

\author{
Beilstein Journal of Organic Chemistry 2009, 5, No. 16 \\ doi:10.3762/bjoc.5.16 \\ Received: 22 January 2009 \\ Accepted: 02 April 2009 \\ Published: 29 April 2009 \\ Guest Editor: A. Kirschning \\ (c) 2009 Nagaki et al; licensee Beilstein-Institut. \\ License and terms: see end of document.
}

\begin{abstract}
A microflow system consisting of micromixers and microtube reactors provides an effective method for the introduction of two electrophiles onto dibromobiaryls. Selective monolithiation of dibromobiaryls, such as 2,2'-dibromobiphenyl, 4,4'-dibromobiphenyl, 2,7-dibromo-9,9-dioctylfluorene, 2,2'-dibromo-1,1'-binaphthyl, and 2,2'-dibromobibenzyl with 1 equiv of $n$-butyllithium followed by the reaction with electrophiles was achieved using a microflow system by virtue of fast micromixing and precise temperature control. Sequential introduction of two different electrophiles was achieved using an integrated microflow system composed of four micromixers and four microtube reactors to obtain unsymmetrically substituted biaryl compounds.
\end{abstract}

\section{Introduction}

Unsymmetrical biaryls have received significant research interest because of the frequent occurrence of such structures in natural products, pharmaceuticals, agrochemicals, and functional organic materials [1]. Transition metal-catalyzed crosscoupling of arylmetal compounds with aryl halides or triflates serves as a useful method for preparation of such unsymmetrical biaryls [2-9]. Selective monolithiation of dihalobiaryls also seems to be useful for synthesis of unsymmetrically substituted biaryls because the remaining halogen atom can be utilized for further transformations [10-12]. However, halogen-lithium exchange reactions of dihalobiaryls usually give a mixture of mono- and dilithiated compounds in a conventional macrobatch reactor, even when one equivalent of butyllithium is used.

Recent investigations revealed that microflow systems [13-26] serve as useful method for improving product selectivity in fast competitive consecutive reactions. If a reaction is faster than mixing, the reaction takes place before the homogeneity of the 
solution is achieved. This often happens in macrobatch reactors such as flasks. In such cases, arguments based on kinetics do not work, and product selectivity is determined by the manner of mixing (disguised chemical selectivity) [27,28]. To obtain a predictable selectivity close to kinetically based one, extremely fast mixing is necessary. Micromixing based on short diffusion paths proved to be quite effective for this purpose [29-33]. Fast heat transfer by virtue of high surface-to-volume ratios in microspaces is also important for conducting fast reactions, because fast reactions are often highly exothermic. Fast reactions often involve unstable short-lived intermediates. In such cases residence time control in microflow system is effective for conducting reactions without decomposing such intermediates [34-40]. Moreover, microflow systems serve as effective ways of integrating chemical reactions, in which an initial product is used for a subsequent transformation [41-51]. For example, sequential introduction of two electrophiles to $p$-, $m$-, and $o$-dibromobenzenes based on $\mathrm{Br}-\mathrm{Li}$ exchange reactions has been accomplished using an integrated microflow system at much higher temperatures than those for conventional macrobatch systems by virtue of residence time control and temperature control $[52,53]$.

Recently, we reported that selective monolithiation can be achieved by extremely fast 1:1 micromixing of dibromobiaryls and $n$-butyllithium using microflow systems [54]. The

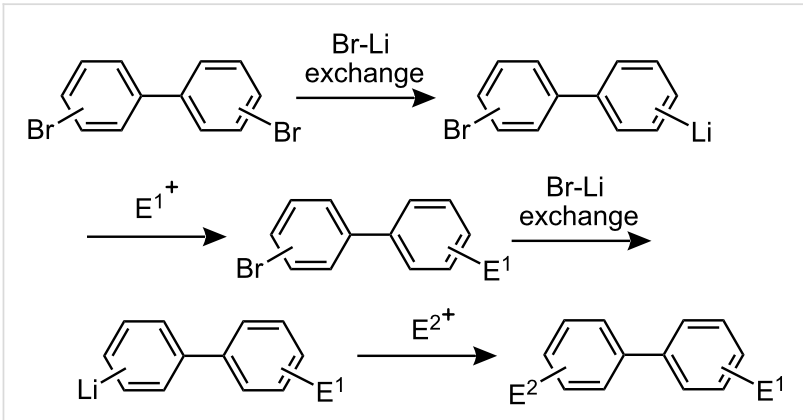

Scheme 1: Sequential introduction of two electrophiles onto dibromobiaryls using Br-Li exchange reactions. successful results prompted us to perform a study on the synthesis of unsymmetrically substituted biaryls via sequential lithiation of dibromobiaryls using an integrated microflow system. These observations may open a new aspect of the synthesis of unsymmetrically substituted biaryls (Scheme 1), and herein we report full details of this study.

\section{Results and Discussion Br-Li Exchange Reaction of 2,2'-Dibromobi- phenyl}

First, we focused on Br-Li exchange reaction of 2,2'-dibromobiphenyl (1) to generate (2-bromobiphenyl-2'-yl)lithium. It is known that Br-Li exchange reaction of 2,2'-dibromobiphenyl (1) gives a significant amount of dilithiated product in a conventional macrobatch system $[55,56]$. In order to confirm this, we reexamined the $\mathrm{Br}-\mathrm{Li}$ exchange reaction of 1 with 1 equiv of $n$-BuLi in a conventional macrobatch reactor (Scheme 2). A hexane solution of $n$-BuLi was added dropwise ( $1 \mathrm{~min}$ ) to a THF solution of $\mathbf{1}$ in a $20 \mathrm{~mL}$ round-bottomed flask at $T^{\circ} \mathrm{C}(T$ $=-78,-48,-27,0$, and 24$)$ to generate (2-bromobiphenyl-2'yl)lithium. After stirring methanol was added, and the mixture was stirred for $10 \mathrm{~min}$. Then, the solution was analyzed by gas chromatography (GC) to determine the yields of 2-bromobiphenyl (2, product derived from monolithiation) and biphenyl (3, product derived from dilithiation).

As shown in Table 1, 2 was obtained with high selectivity at $-78{ }^{\circ} \mathrm{C}$, but the yield was not very high. Moreover, the requirement of such low temperatures like $-78^{\circ} \mathrm{C}$ causes severe limita-

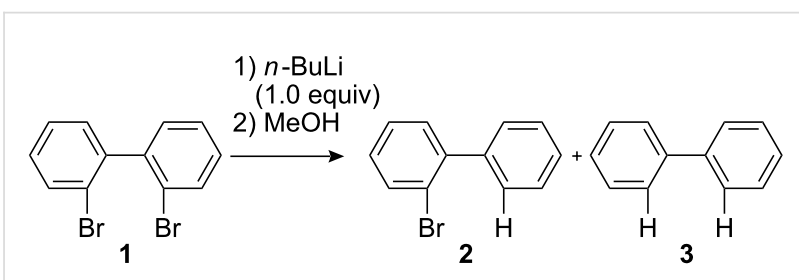

Scheme 2: Br-Li exchange reaction of 2,2'-dibromobiphenyl (1) with $n$-BuLi using a conventional macrobatch reactor.

\begin{tabular}{|c|c|c|c|c|c|}
\hline temperature $\left({ }^{\circ} \mathrm{C}\right)$ & reaction time (min) & 1 conversion $(\%)^{b}$ & 2 yield $(\%)^{b}$ & 3 yield $(\%)^{b}$ & 4 yield $(\%)^{b}$ \\
\hline-78 & 60 & 94 & 76 & 4 & 0 \\
\hline-48 & 10 & 86 & 69 & 4 & 0 \\
\hline-27 & 10 & 81 & 48 & 18 & 0 \\
\hline 0 & 10 & 75 & 36 & 25 & 2 \\
\hline 24 & 10 & 66 & 14 & 34 & 3 \\
\hline
\end{tabular}

${ }^{a}$ A solution of $1(0.10 \mathrm{M}, 6.0 \mathrm{~mL})$ in THF was stirred in a flask $(20 \mathrm{~mL})$. A solution of $n$-BuLi $(0.50 \mathrm{M}, 1.2 \mathrm{~mL})$ in hexane was added dropwise for $1.0 \mathrm{~min}$. After stirring, methanol (neat, $3.0 \mathrm{~mL}$ ) was added dropwise for $1.0 \mathrm{~min}$. After stirring for $10 \mathrm{~min}$, the mixture was analyzed. ${ }^{b}$ Determined by $\mathrm{GC}$. 


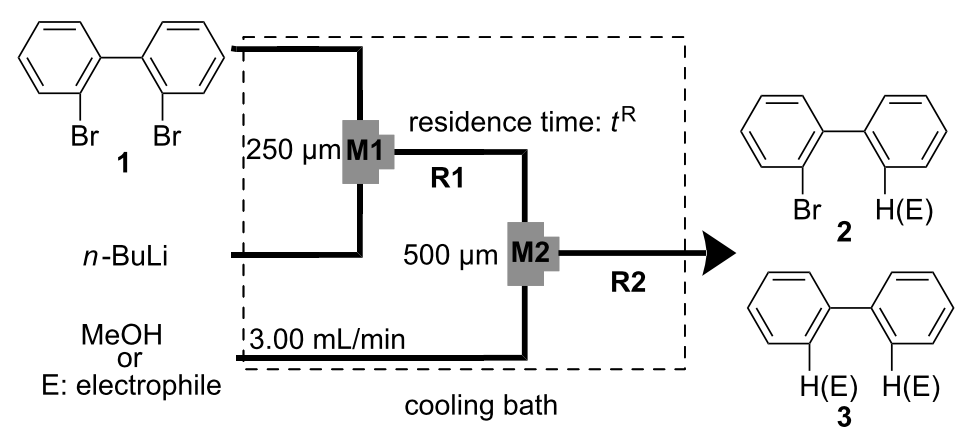

Figure 1: Microflow system for Br-Li exchange reaction of 2,2'-dibromobiphenyl (1). T-shaped micromixer: M1 $(\varnothing=250 \mu \mathrm{m})$ and $\mathbf{M} 2$ ( $\varnothing=500 \mu \mathrm{m})$, microtube reactor: $\mathbf{R} 1$ and $\mathbf{R 2}(\varnothing=1000 \mu \mathrm{m}, I=50 \mathrm{~cm})$, a solution of 2,2'-dibromobiphenyl (1): $0.10 \mathrm{M}$ in THF, a solution of $n$-BuLi: $0.50 \mathrm{M}$ in hexane, a solution of electrophile: $0.30 \mathrm{M}$ in THF.

tions in the industrial application. The selectivity decreased with an increase in the temperature, and a significant amount of 3 was produced at higher temperatures. The major side product was 2-bromo-2'-butylbiphenyl (4), which seemed to be produced by the reaction of (2-bromobiphenyl-2'-yl)lithium with 1-bromobutane that was produced by $\mathrm{Br}-\mathrm{Li}$ exchange reaction.

In the next step, the same reaction was examined using a microflow system composed of two T-shaped micromixers (M1 and M2) and two microtube reactors ( $\mathbf{R} 1$ and $\mathbf{R 2}$ ) shown in Figure 1. A solution of $2,2^{\prime}$-dibromobiphenyl (1) $(0.10 \mathrm{M})$ in THF (flow rate: $6.00 \mathrm{ml} \cdot \mathrm{min}^{-1}, 0.60 \mathrm{mmol} \mathrm{min}-1$ ) and a solution of $n$-BuLi $(0.50 \mathrm{M})$ in hexane (flow rate: $1.20 \mathrm{ml} \cdot \mathrm{min}^{-1}, 0.60$ mmol $\left.\min ^{-1}\right)$ were introduced to $\mathbf{M 1}(\varnothing=250 \mu \mathrm{m})$ by syringe pumping. The mixture was passed through $\mathbf{R} \mathbf{1}$ (residence time $=$ $\left.t^{\mathrm{R}} \mathrm{s}\right)$ and was introduced to $\mathbf{M} 2(\varnothing=500 \mu \mathrm{m})$, where methanol (neat, flow rate: $3.00 \mathrm{ml} \cdot \mathrm{min}^{-1}$ ) was introduced. The resulting mixture was passed through $\mathbf{R} 2\left(\varnothing=1000 \mu \mathrm{m}, l=50 \mathrm{~cm}, t^{\mathrm{R}}=\right.$ $2.3 \mathrm{~s}$ ). The temperature for the $\mathrm{Br}-\mathrm{Li}$ exchange reaction and that for the quenching with methanol were controlled by adjusting the temperature of a cooling bath. The residence time $\left(t^{\mathrm{R}}\right)$ was adjusted by changing the length of the microtube reactor R1 with a fixed flow rate. After a steady state was reached, an aliquot of the product solution was taken for $60 \mathrm{~s}$. The amount of 2-bromobiphenyl (2) and that of biphenyl (3) were determined by GC.

The results obtained with varying temperature $\left(-78\right.$ to $\left.24{ }^{\circ} \mathrm{C}\right)$ and residence time $\left(t^{\mathrm{R}}\right)$ in $\mathbf{R} 1(0.057-13 \mathrm{~s})$ are shown in Figure 2 (see the Supporting Information for details). High yields and high selectivities were obtained even at $0{ }^{\circ} \mathrm{C}\left(t^{\mathrm{R}}=0.057 \mathrm{~s}: 2\right.$ $(88 \%)$ and $3(3 \%))$, and $24{ }^{\circ} \mathrm{C}\left(t^{\mathrm{R}}=0.057 \mathrm{~s}: \mathbf{2}(85 \%)\right.$ and 3 $(4 \%)$ ), demonstrating a significant advantage of the microflow system. Extremely fast heat transfer of the microflow system seems to be responsible for these results. In other words, Br- $\mathrm{Li}$ exchange reaction can be inherently conducted at $0{ }^{\circ} \mathrm{C}$ and 24 ${ }^{\circ} \mathrm{C}$, while the reaction in macrobatch reactors suffers from insufficient heat removal, and therefore, over-cooling is necessary. At $-48^{\circ} \mathrm{C}$ and $-78^{\circ} \mathrm{C}$, the $\mathrm{Br}-\mathrm{Li}$ exchange reaction was not complete within $0.1 \mathrm{~s}$. At higher temperatures, however, the $\mathrm{Br}-\mathrm{Li}$ exchange reaction was complete within $0.1 \mathrm{~s}$.

(a)

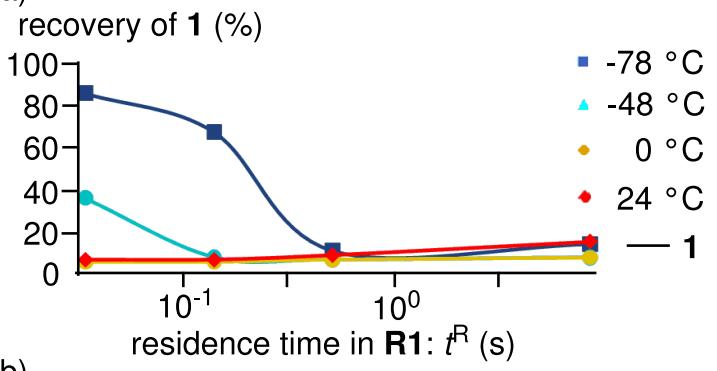

(b)

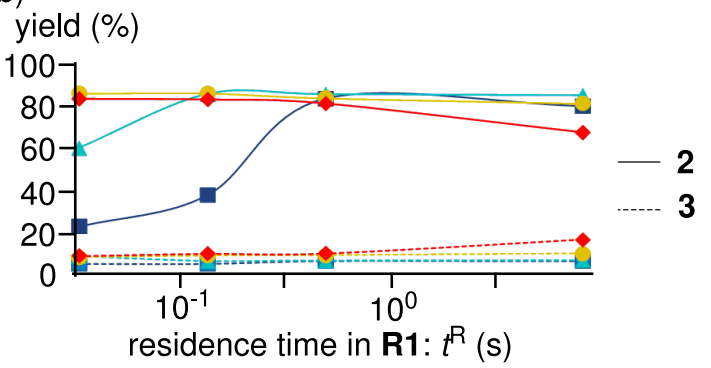

Figure 2: Effect of temperature and residence time in $\mathrm{Br}-\mathrm{Li}$ exchange reaction of 2,2'-dibromobiphenyl (1) using the microflow system; (a) plots of recovery of 1 against the residence time, (b) plots of yields of 2 and 3 against the residence time. Flow rate of a solution of 2,2'-dibromobiphenyl (1): $6.00 \mathrm{ml} \cdot \mathrm{min}^{-1}$, flow rate of $n$-BuLi: $1.20 \mathrm{ml} \cdot \mathrm{min}^{-1}$, flow rate of methanol: $3.00 \mathrm{ml} \cdot \mathrm{min}^{-1}$. Yields of 1, 2 and 3 were determined by GC.

As shown in Table 2, the selectivity increased with a decrease in the diameter of M1, presumably because faster mixing can be achieved with a mixer of a smaller diameter. The selectivity also increased with an increase in the flow rate. It is known that 


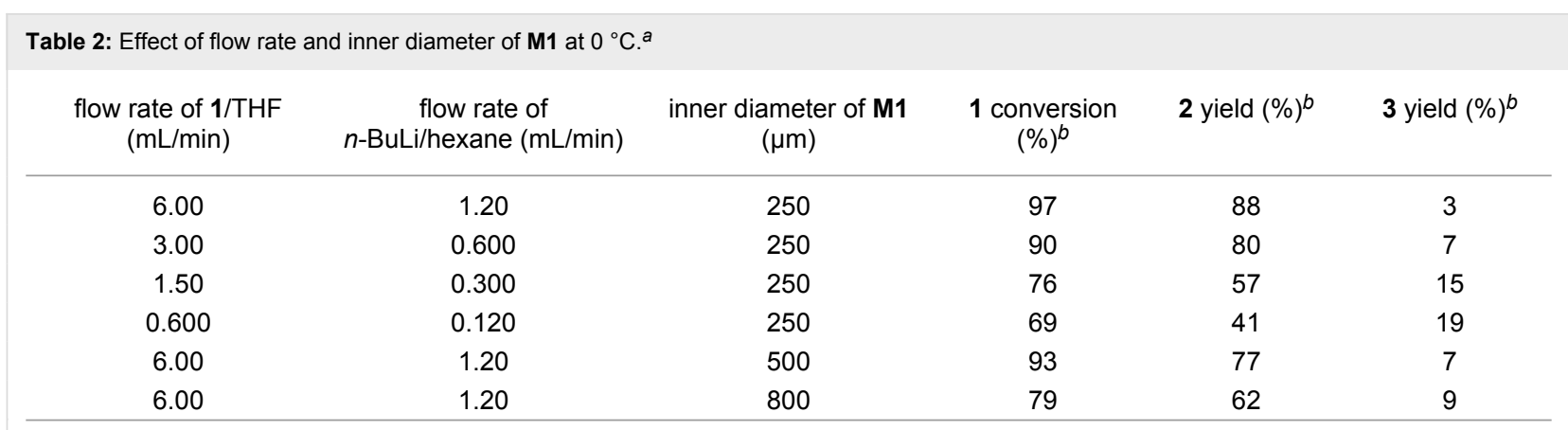

${ }^{a} \mathbf{R} 1: \varnothing=500 \mu \mathrm{m}, I=3.5 \mathrm{~cm}$, flow rate of methanol: $3.00 \mathrm{ml} \cdot \mathrm{min}^{-1} .{ }^{b}$ Determined by $\mathrm{GC}$.

the mixing rate increases with an increase in the flow rate for other types of micromixers [57]. These observations indicate that extremely fast 1:1 mixing in the microflow system is responsible for selective monolithiation at much higher temper-

Table 3: Br-Li exchange reaction of 2,2'-dibromobiphenyl (1) followed by reaction with an electrophile using the microflow system. ${ }^{a}$

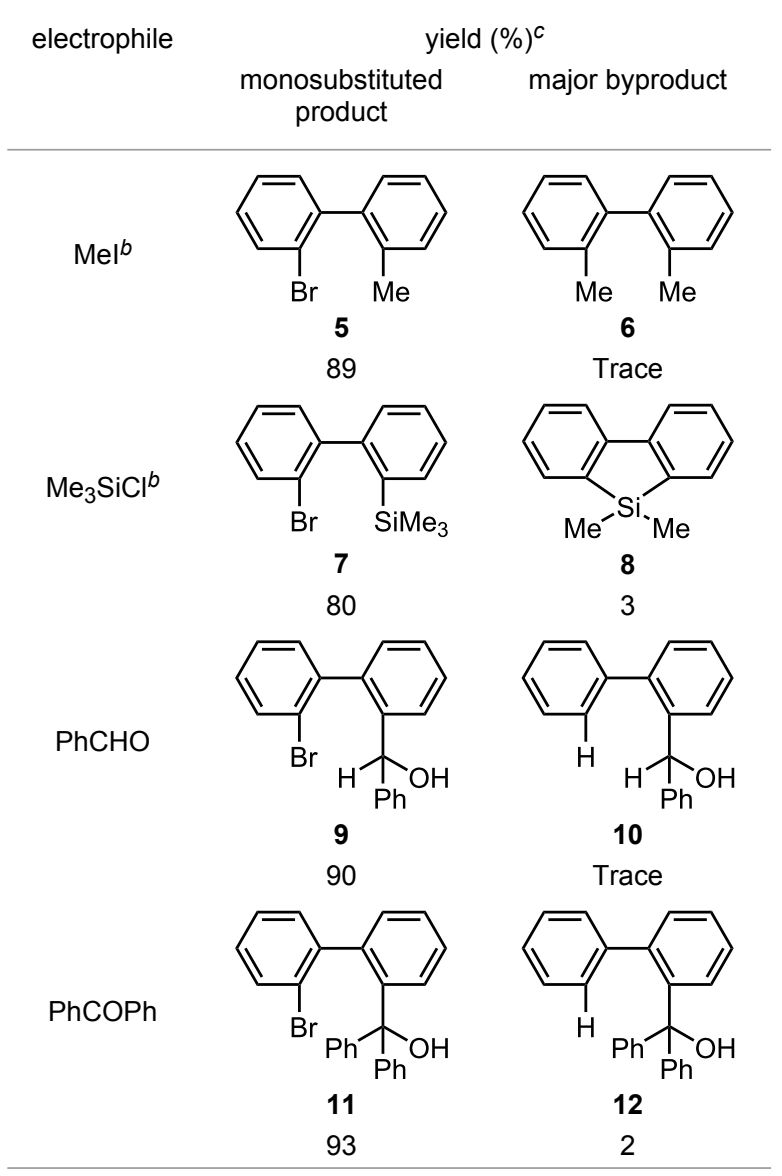

a Flow rate of a solution of $1: 6.00 \mathrm{ml} \cdot \mathrm{min}^{-1}$, flow rate of $n-\mathrm{BuLi} /$ hexane: $1.20 \mathrm{ml} \cdot \mathrm{min}^{-1}, \mathbf{R} 1: \varnothing=500 \mu \mathrm{m}, l=3.5 \mathrm{~cm}\left(t^{\mathrm{R}}=0.057 \mathrm{~s}\right)$. The conversion was higher than $95 \%$ in all cases. ${ }^{b} \mathbf{R 2}: \varnothing=1000 \mu \mathrm{m}, I=200 \mathrm{~cm}$, flow rate of a solution of an electrophile: $4.00 \mathrm{ml} \cdot \mathrm{min}^{-1}$. ${ }^{c}$ Determined by GC. atures such as $0{ }^{\circ} \mathrm{C}$ and $24^{\circ} \mathrm{C}$ than those required for a conventional macrobatch processes.

Under the optimized reaction conditions (reaction temperature: $\left.0{ }^{\circ} \mathrm{C}, t^{\mathrm{R}}: 0.057 \mathrm{~s}\right)$, reactions using other electrophiles $(0.30 \mathrm{M}$ in THF) were examined. In all cases, the conversion of 1 was higher than $95 \%$. As summarized in Table 3 , the reaction with iodomethane gave 2-bromo-2'-methylbiphenyl (5) in 89\% yield with high selectivity. Chlorotrimethylsilane, benzaldehyde, and benzophenone were also effective as electrophiles, and the corresponding products derived from the monolithiated species were obtained selectively in high yields. These results show that the microflow system serves as an useful method for selective monolithiation of 2,2'-dibromobiphenyl (1) followed by the reaction with electrophiles.

\section{Synthesis of Unsymmetrically Substituted Biaryls from 2,2'-Dibromobiphenyl (1) by} Sequential Introduction of Two Electrophiles

With successful monolithiation of 2,2'-dibromobiphenyl (1) followed by the reaction with an electrophile using the microflow system in hand, sequential introduction of two electrophiles $\left(E^{1}\right.$ and $E^{2}$ ) onto 2,2'-dibromobiphenyl (1) was examined using an integrated microflow system composed of four T-shaped micromixers (M1, M2, M3 and M4) and four microtube reactors (R1, R2, R3 and R4) shown in Figure 3. In this case, T-shaped micromixers M3 and M4 having the inside diameter of $500 \mu \mathrm{m}$ were used to suppress the pressure increase because an increase in the numbers of micromixers and microtube reactors in the system causes a signficant pressure increase.

A solution of 2,2'-dibromobiphenyl (1) (0.10 M) in THF (flow

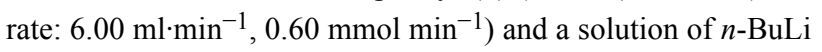
$(0.50 \mathrm{M})$ in hexane (flow rate: $1.20 \mathrm{ml} \cdot \mathrm{min}^{-1}, 0.60$ $\left.\mathrm{mmol} \cdot \mathrm{min}^{-1}\right)$ were introduced to $\mathbf{M 1}(\varnothing=250 \mu \mathrm{m})$ by syringe pumping. The mixture was passed through $\mathbf{R} 1(\varnothing=500 \mu \mathrm{m}, l=$ $\left.3.5 \mathrm{~cm}, t^{\mathrm{R}}=0.057 \mathrm{~s}\right)$ and the resulting solution was introduced to $\mathbf{M} 2(\varnothing=500 \mu \mathrm{m})$, where a solution of a first electrophile $\left(\mathrm{E}^{1}\right)$ 


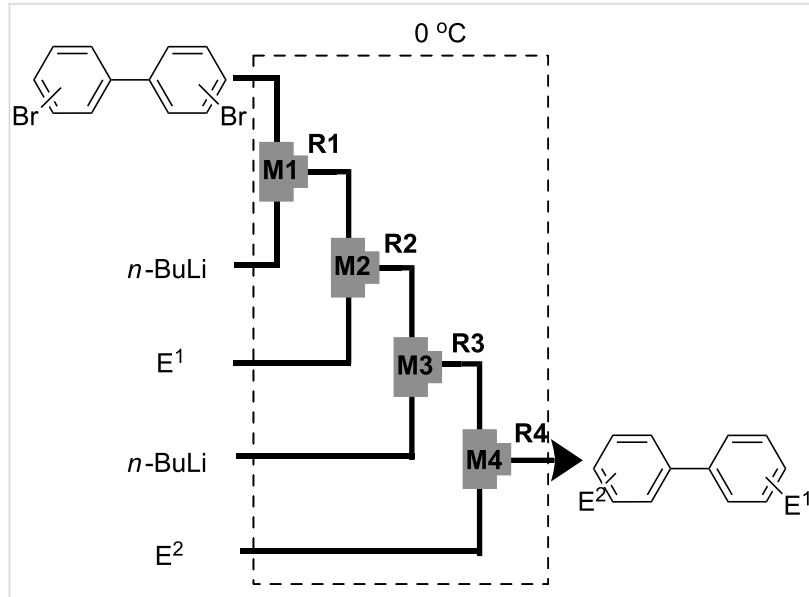

Figure 3: A microflow system for sequential introduction of two electrophiles. T-shaped micromixer: M1 $(\varnothing=250 \mu \mathrm{m}), \mathbf{M} 2(\varnothing=500 \mu \mathrm{m}), \mathbf{M} 3$ $(\varnothing=500 \mu \mathrm{m})$, and M4 $(\varnothing=500 \mu \mathrm{m})$, microtube reactor: R1 $(\varnothing=500$ $\left.\mu \mathrm{m}, I=3.5 \mathrm{~cm}\left(t^{\mathrm{R}:} 0.057 \mathrm{~s}\right)\right), \mathbf{R} 2\left(\varnothing=1000 \mu \mathrm{m}, I=200 \mathrm{~cm}\left(t^{\mathrm{R}:}: 9.8 \mathrm{~s}\right)\right)$, R3 $\left(\varnothing=1000 \mu \mathrm{m}, I=200 \mathrm{~cm}\left(t^{\mathrm{R}:}: 8.5 \mathrm{~s}\right)\right)$, and R4 $(\varnothing=1000 \mu \mathrm{m}, I=50$ $\left.\mathrm{cm}\left(t^{R:}: 1.8 \mathrm{~s}\right)\right)$. Flow rate of a solution of a dibromobiaryl $(0.10 \mathrm{M}$ in THF): $6.00 \mathrm{ml} \cdot \mathrm{min}^{-1}$, flow rate of $n$-BuLi ( $0.50 \mathrm{M}$ in hexane): 1.20 $\mathrm{ml} \cdot \mathrm{min}^{-1}$, flow rate of a solution of a first electrophile $\left(E^{-1}\right)(0.50 \mathrm{M}$ in THF): $2.40 \mathrm{ml} \cdot \mathrm{min}^{-1}$. flow rate of $n$-BuLi (1.00 M in hexane): 1.44 $\mathrm{ml} \cdot \mathrm{min}^{-1}$, flow rate of a solution of a second electrophile $\left(E^{2}\right)(0.90 \mathrm{M}$ in THF): $2.00 \mathrm{ml} \cdot \mathrm{min}^{-1}$.

$(0.50 \mathrm{M})$ in THF (flow rate: $2.40 \mathrm{ml} \cdot \mathrm{min}^{-1}, 1.20 \mathrm{mmol} \cdot \mathrm{min}^{-1}$ ) was introduced. The mixture was passed through $\mathbf{R 2}(\varnothing=1000$ $\mu \mathrm{m}, l=200 \mathrm{~cm}, t^{\mathrm{R}}=9.8 \mathrm{~s}$ ) and the resulting solution containing a monobromo compound was introduced to $\mathbf{M 3}(\varnothing=500 \mu \mathrm{m})$, where a solution of $n$-BuLi $(1.0 \mathrm{M})$ in hexane (flow rate: 1.44 $\mathrm{ml} \cdot \mathrm{min}^{-1}, 1.44 \mathrm{mmol} \cdot \mathrm{min}^{-1}$ ) was introduced. The mixture was passed through $\mathbf{R 3}\left(\varnothing=1000 \mu \mathrm{m}, l=200 \mathrm{~cm}, t^{\mathrm{R}}=8.5 \mathrm{~s}\right)$ and the resulting solution containing a second aryllithium intermediate was introduced to M4 $(\varnothing=500 \mu \mathrm{m})$, where a solution of a second electrophile $\left(\mathrm{E}^{2}\right)(0.90 \mathrm{M})$ in THF (flow rate: 2.00 $\left.\mathrm{mL} \cdot \mathrm{min}^{-1}, 1.80 \mathrm{mmol} \cdot \mathrm{min}^{-1}\right)$ was introduced. Themixture was passed through $\mathbf{R} 4\left(\varnothing=1000 \mu \mathrm{m}, l=50 \mathrm{~cm}, t^{\mathrm{R}}=1.8 \mathrm{~s}\right)$. The all processes were conducted at $0{ }^{\circ} \mathrm{C}$.

As summarized in Table 4, the sequential introductions of two electrophiles were achieved successfully with various combinations of electrophiles without isolation of monobromo biaryl compound. It is interesting to note that the use of an aldehyde $\left(\mathrm{E}^{1}\right)$ and methyl chlorocarbonate $\left(\mathrm{E}^{2}\right)$ as electrophiles led to effective formation of a seven-membered ring lactone. This integrated microflow synthesis serves as a straightforward and powerful method for synthesizing unsymmetrically substituted biaryls from 2,2'-dibromobiphenyl (1) and two electrophiles.

\section{Br-Li Exchange Reaction of 4,4'-Dibromobi- phenyl}

Next, we examined Br-Li exchange reaction of 4,4'-dibromobiphenyl (17) with $n$-BuLi. The temperature effect for a
Table 4: Synthesis of unsymmetrically substituted biaryls from 2,2'dibromobiphenyl (1) by sequential introduction of two electrophiles. ${ }^{a}$

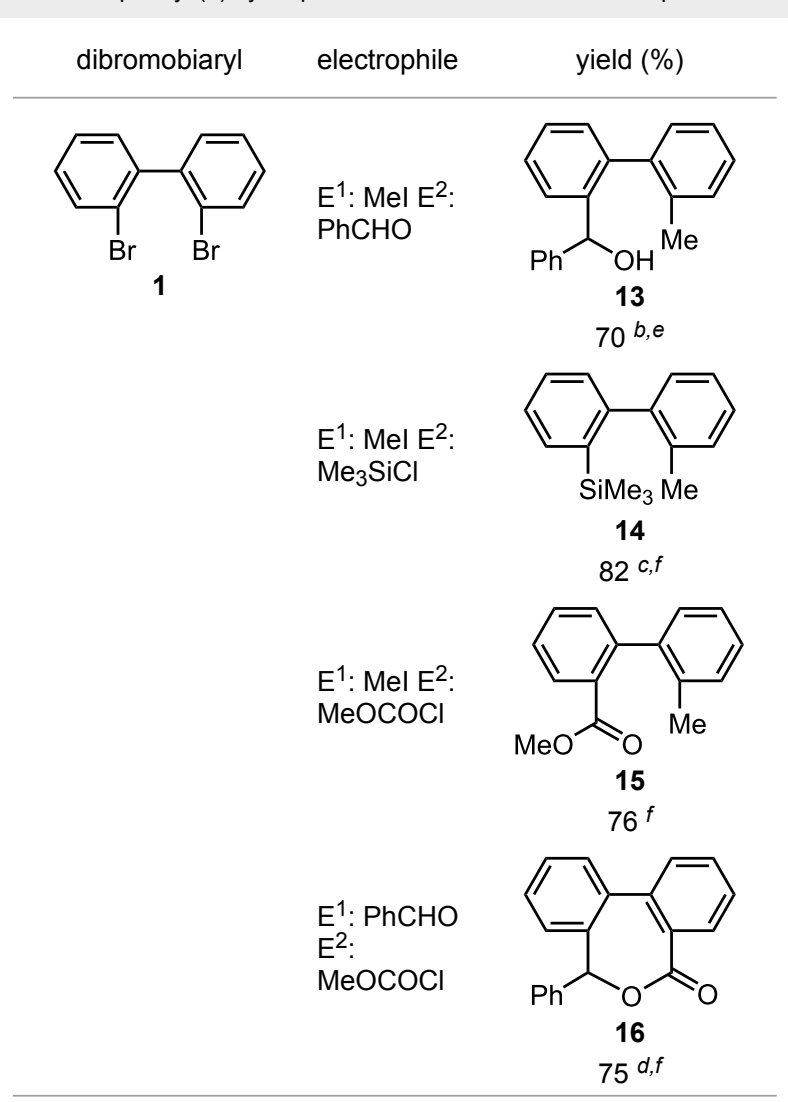

${ }^{a}$ Reactions were conducted in the microflow system shown in Figure 3 unless otherwise stated. ${ }^{b}$ 2-Methylbiphenyl was also produced as a byproduct. ${ }^{C} \mathbf{R} 4: \varnothing=1000 \mu \mathrm{m}, I=200 \mathrm{~cm}{ }^{d} \mathbf{R} 2: ~ \varnothing=1000 \mu \mathrm{m}, I=50 \mathrm{~cm}$, benzaldehyde $(0.30 \mathrm{M})$, methyl chlorocarbonate $(0.30 \mathrm{M})^{e}{ }^{e}$ ssolated yield. fDetermined by GC.

macrobatch reaction was studied (Scheme 3 ) and the results are summarized in Table 5 .

4-Bromobiphenyl (18) was obtained with high yield and selectivity at $-78{ }^{\circ} \mathrm{C}$. However, the yield and selectivity decreased with an increase in the temperature. At higher temperatures 4-bromo-4'-butylbiphenyl (19) was produced presumably by the reaction of (4-bromobiphenyl-4'-yl)lithium

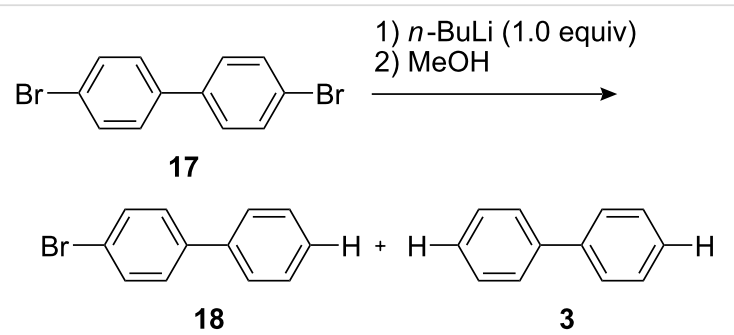

Scheme 3: Br-Li exchange reaction of 4,4'-dibromobiphenyl (17) with $n$-BuLi using a conventional macrobatch reactor. 


\begin{tabular}{|cccccc}
\hline $\begin{array}{l}\text { Table 5: Br-Li exchange reaction of } 4,4^{\prime} \text {-dibromobiphenyl }(\mathbf{1 7}) \text { using a conventional macrobatch system. } \\
\text { temperature }\left({ }^{\circ} \mathbf{C}\right)\end{array}$ & reaction time $(\mathbf{m i n})$ & $\mathbf{1 7}$ conversion $(\%)^{b}$ & $\mathbf{1 8}$ yield $(\%)^{b}$ & $\mathbf{3}$ yield $(\%)^{b}$ & $\mathbf{1 9}$ yield $(\%)^{b}$ \\
\hline-78 & 60 & 95 & 87 & 5 & 0 \\
-48 & 10 & 90 & 49 & 5 & 0 \\
-27 & 10 & 81 & 56 & 5 & 2 \\
0 & 10 & 86 & 47 & 6 & 13 \\
24 & 10 & 87 & 25 & 2 & 26 \\
\hline
\end{tabular}

${ }^{a}$ A solution of $17(0.10 \mathrm{M}, 6.0 \mathrm{~mL})$ in THF was stirred in a flask $(20 \mathrm{~mL})$. A solution of $n$-BuLi $(0.50 \mathrm{M}, 1.2 \mathrm{~mL})$ in hexane was added dropwise for 1.0 $\mathrm{min}$. After stirring, methanol (neat, $3.0 \mathrm{~mL}$ ) was added dropwise for $1.0 \mathrm{~min}$. After stirring for $10 \mathrm{~min}$, the mixture was analyzed. ${ }^{b}$ Determined by $\mathrm{GC}$.

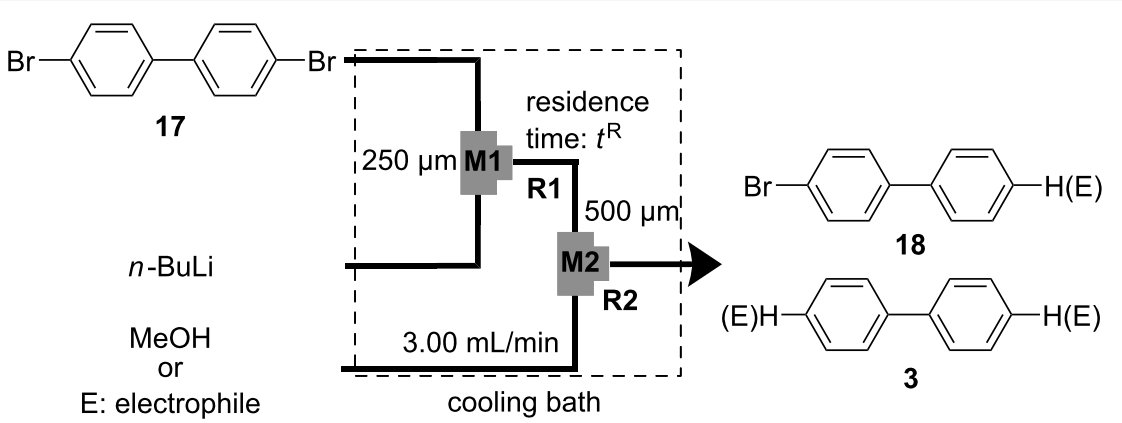

Figure 4: Microflow system for $\mathrm{Br}$-Li exchange reaction of 4,4'-dibromobiphenyl (17). T-shaped micromixer: $\mathbf{M} 1(\varnothing=250 \mu \mathrm{m})$ and $\mathbf{M} 2(\varnothing=500 \mu \mathrm{m})$, microtube reactor: $\mathbf{R} 1$ and $\mathbf{R} 2(\varnothing=1000 \mu \mathrm{m}, I=50 \mathrm{~cm}$ ), a solution of 4,4'-dibromobiphenyl (17): $0.10 \mathrm{M}$ in THF, a solution of $n$-BuLi: $0.50 \mathrm{M}$ in hexane, a solution of an electrophile: $0.30 \mathrm{M}$ in THF.

with 1-bromobutane that was produced by $\mathrm{Br}-\mathrm{Li}$ exchange reaction.

In the next step, the reaction was carried out using a microflow system composed of two T-shaped micromixers (M1 and M2) and two microtube reactors (R1 and R2) shown in Figure 4. A solution of 4,4'-dibromobiphenyl (17) $(0.10 \mathrm{M})$ in THF (flow rate: $\left.6.00 \mathrm{~mL} \cdot \mathrm{min}^{-1}, 0.60 \mathrm{mmol} \cdot \mathrm{min}^{-1}\right)$ and a solution of $n$-BuLi $(0.50 \mathrm{M})$ in hexane (flow rate: $1.20 \mathrm{~mL} \cdot \mathrm{min}^{-1}, 0.60$ $\left.\mathrm{mmol} \cdot \mathrm{min}^{-1}\right)$ were introduced to $\mathbf{M 1}(\varnothing=250 \mu \mathrm{m})$ by syringe pumping. The mixture was passed through $\mathbf{R} \mathbf{1}$ (residence time $=$ $\left.t^{\mathrm{R}} \mathrm{sec}\right)$ and was introduced to $\mathbf{M 2}(\varnothing=500 \mu \mathrm{m})$, where methanol (neat, flow rate: $3.00 \mathrm{ml} \cdot \mathrm{min}^{-1}$ ) was introduced. The resulting mixture was passed through $\mathbf{R 2}(\varnothing=1000 \mu \mathrm{m}, l=50$ $\left.\mathrm{cm}, t^{\mathrm{R}}=2.3 \mathrm{~s}\right)$. The temperature for the $\mathrm{Br}-\mathrm{Li}$ exchange reaction and the quenching with methanol was controlled by adjusting the temperature of a cooling bath. The residence time was adjusted by changing the length of the microtube reactor R1 with a fixed flow rate. After a steady state was reached, an aliquot of the product solution was taken for $60 \mathrm{~s}$. The amount of 4-bromobiphenyl (18, product derived from monolithiation) and biphenyl (3, product derived from dilithiation) was determined by GC.

The results obtained with varying temperature $\left(-78\right.$ to $\left.24{ }^{\circ} \mathrm{C}\right)$ and residence time in $\mathbf{R} 1(0.057-13 \mathrm{~s})$ are shown in Figure 5 (a)

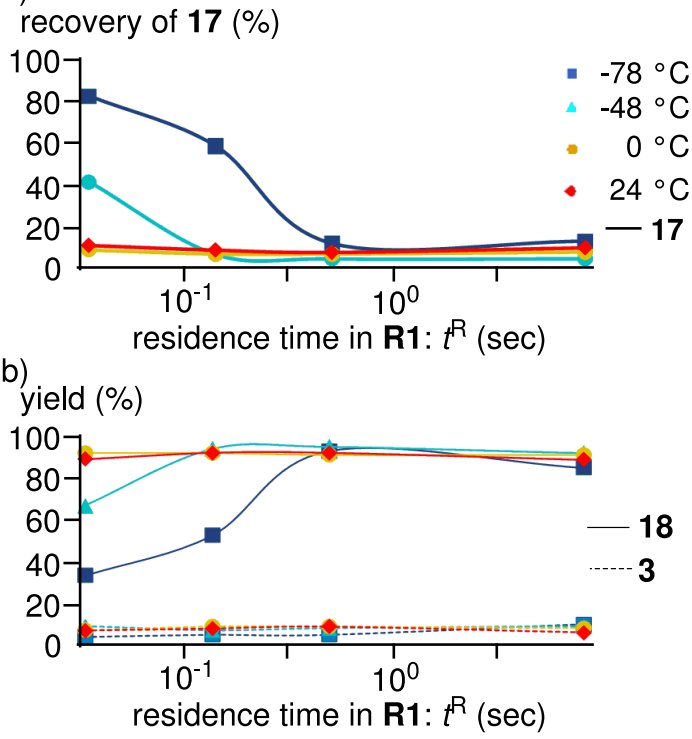

Figure 5: Effect of temperature and residence time in $\mathrm{Br}-\mathrm{Li}$ exchange reaction of 4,4'-dibromobiphenyl (17) using the microflow system; (a) Plots of recovery of $\mathbf{1 7}$ against residence time, (b) Plots of yields of 18 and 3 against residence time. Flow rate of a solution of 4,4'-dibromobiphenyl (17): $6.00 \mathrm{~mL} \cdot \mathrm{min}^{-1}$, flow rate of $n$-BuLi/hexane: $1.20 \mathrm{~mL} \cdot \mathrm{min}^{-1}$ flow rate of methanol: $3.00 \mathrm{~mL} \cdot \mathrm{min}^{-1}$. Yields of 3,17 and 18 were determined by GC. 
Table 6: Br-Li exchange reaction of 4,4'-dibromobiphenyl (17) followed by the reaction with an electrophile using the microflow system. ${ }^{a}$

electrophile

${ }^{a}$ Flow rate of a solution of $17: 6.00 \mathrm{~mL} \cdot \mathrm{min}^{-1}$, flow rate of $n$-BuLi/hexane: $1.20 \mathrm{~mL} \cdot \mathrm{min}, \mathbf{R} 1: \varnothing=500 \mu \mathrm{m}, I=3.5 \mathrm{~cm}\left(t^{\mathrm{R}}=0.057 \mathrm{~s}\right) .{ }^{b} \mathbf{R 2}: \varnothing=1000 \mu \mathrm{m}, I$ $=200 \mathrm{~cm}$, flow rate of a solution of an electrophile: $4.00 \mathrm{~mL} \cdot \mathrm{min}^{-1}$. ${ }^{c}$ Determined by GC. ${ }^{d}$ Isolated yield.

(see the Supporting Information for details). High yields and high selectivities were obtained even at $0{ }^{\circ} \mathrm{C}$ (residence time of $\mathbf{R 1}=0.057 \mathrm{~s}: \mathbf{1 8}(88 \%)$ and $3(4 \%))$ and $24{ }^{\circ} \mathrm{C}$ (residence time of $\mathbf{R 1}=0.057 \mathrm{s:} \mathbf{1 8}(85 \%)$ and $\mathbf{3}(4 \%))$. At $-48^{\circ} \mathrm{C}$ and $-78{ }^{\circ} \mathrm{C}$, the $\mathrm{Br}-\mathrm{Li}$ exchange reaction was not complete within $0.1 \mathrm{~s}$. At higher temperatures, however, the $\mathrm{Br}-\mathrm{Li}$ exchange reaction was complete within $0.1 \mathrm{~s}$. These tendencies are quite similar to those for the 2,2'-dibromobiphenyl (1) case. Therefore, it is reasonable to consider that (2-bromobiphenyl-2'-yl)lithium and (4-bromobiphenyl-4'-yl)lithium have similar thermal stability.
Under the optimized reaction conditions (reaction temperature: $\left.0{ }^{\circ} \mathrm{C}, t^{\mathrm{R}}: 0.057 \mathrm{~s}\right)$, reactions using other electrophiles $(0.30 \mathrm{M}$ in THF) such as iodomethane, benzaldehyde, and benzophenone were examined to obtain the corresponding products in good yields at $0{ }^{\circ} \mathrm{C}$ as shown in Table 6 . These results show that microflow system serves as an useful method for selective monolithiation of 4,4'-dibromobiphenyl (17) followed by the reaction with electrophiles.

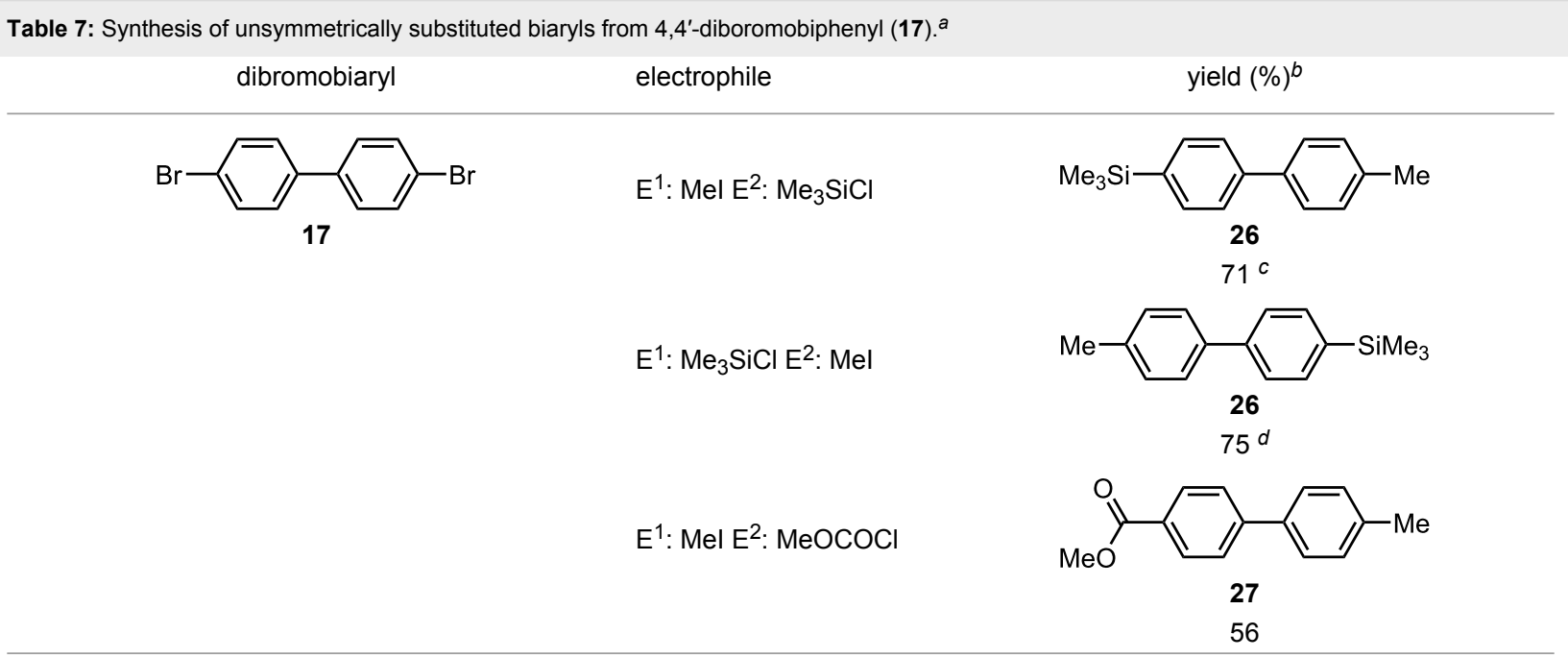

${ }^{a}$ Reactions were conducted in the microflow system shown in Figure 3 unless otherwise stated. ${ }^{b}$ Determined by GC. ${ }^{c} \mathbf{R 4}: \varnothing=1000 \mu \mathrm{m}, I=200 \mathrm{~cm}$. ${ }^{d} \mathbf{R} 4: \varnothing=1000 \mu \mathrm{m}, I=200 \mathrm{~cm}$, flow rate of a solution of chlorotrimethylsilane $(0.30 \mathrm{M}): 2.00 \mathrm{~mL} \cdot \mathrm{min}^{-1}$, flow rate of a solution of iodomethane $(0.50 \mathrm{M})$ : $2.40 \mathrm{~mL} \cdot \mathrm{min}^{-1}$. 
Table 8: Br-Li exchange reaction of other dibromobiaryls $(28,36)$ and 2,2'-dibromobibenzyl $(43)$ followed by reactions with electrophiles.

$\begin{array}{cccc}\text { dibromo compound } & \begin{array}{l}\text { reaction } \\ \text { system }\end{array} & \text { temp. }\left({ }^{\circ} \mathrm{C}\right) & \text { electrophile } \\ & & \begin{array}{c}\text { monosubstituted }(\%) \\ \text { product }\end{array}\end{array}$<smiles>CC1(C)c2cc(Br)ccc2-c2ccc(Br)cc21</smiles>

28

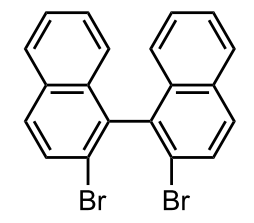

36 macrobatch $^{b, c}$

macrobatch $^{c, d}$

microflow

microflow

microflow ${ }^{e}$

microflow

$-78$

$$
0
$$

0

24

0

0

$\mathrm{PhCHO}$

$\mathrm{MeOH}$
$\mathrm{MeOH}$
$\mathrm{MeOH}$
$\mathrm{MeOH}$
$\mathrm{Mel}$
$\mathrm{PhCHO}$

E: $-\mathrm{H}$

E: $-\mathrm{H}$

E: $-\mathrm{H}$

E: $-\mathrm{H}$

E: -Me

$\mathrm{E}:$ $-\mathrm{CH}(\mathrm{OH}) \mathrm{Ph}$

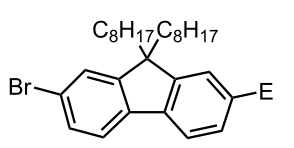

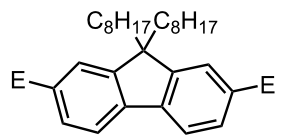

89

(29)

$54^{f}$

95

92

93

(32)

$90^{9}$

(34)

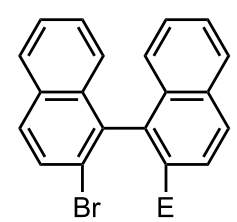

90

(37)

86

93

92

85

(39)

$82^{g}$

(41)
6

(30)

5

4

5

3

(33)

$2^{g}$

(35)

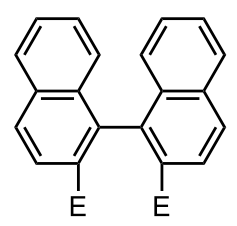

10

(38)

13

1

2

Trace

(40)

trace $^{g}$

(42)

microflow 0

microflow 24

microflow $^{e} \quad 0$

microflow

$\mathrm{PhCHO}$

E: $-\mathrm{CH}(\mathrm{OH}) \mathrm{Ph}$<smiles>Fc1ccccc1CCc1ccccc1Br</smiles>
85<smiles>Brc1ccccc1CCc1ccccc1Br</smiles>

43

macrobatch $^{b, c}$

$-78$

$\mathrm{MeOH}$

E: $-\mathrm{H}$

$\mathrm{MeOH}$

E: $-\mathrm{H}$

macrobatch $^{c, d}$

$\mathrm{MeOH}$

$\mathrm{MeOH}$

E: $-\mathrm{H}$

microflow

Mel

E: $-\mathrm{H}$

E: -Me

$\mathrm{PhCHO}$

E:

$-\mathrm{CH}(\mathrm{OH}) \mathrm{Ph}$
(44)

27

80

77

81

(46)

$66^{g}$

(48)<smiles>Fc1ccccc1CCc1ccccc1F</smiles>

10

(45)

15

10

11

4

(47)

$7^{g}$

(49)

aMicroflow reactions were carried out under the following conditions unless otherwise stated. R1: $\varnothing=500 \mu \mathrm{m}, I=3.5 \mathrm{~cm}, \mathbf{R 2}: \varnothing=1000 \mu \mathrm{m}, I=50 \mathrm{~cm}$, flow rate of a solution of a dibromobiaryl compound: $6.00 \mathrm{~mL} \cdot \mathrm{min}^{-1}$, flow rate of $n$-BuLi/hexane: $1.20 \mathrm{~mL} \cdot \mathrm{min}^{-1}$, flow rate of a solution of an electrophile: $3.00 \mathrm{~mL} \cdot \mathrm{min}^{-1}$. Yields were determined by GC otherwise stated. ${ }^{b}$ Reaction time: $60 \mathrm{~min} .{ }^{c} \mathrm{~A}$ solution of dibromo compound (0.10 M, $\left.6.0 \mathrm{~mL}\right)$ in THF was stirred in a flask $(20 \mathrm{~mL})$. A solution of $n$-BuLi $(0.50 \mathrm{M}, 1.2 \mathrm{~mL})$ in hexane was added dropwise for 1.0 min. After stirring, methanol (neat, $3.0 \mathrm{~mL})$ was added dropwise for $1.0 \mathrm{~min}$. After stirring for $10 \mathrm{~min}$, the mixture was analyzed. ${ }^{d}$ Reaction time: $10 \mathrm{~min}$. ${ }^{e} \mathbf{R 2}: \varnothing=1000 \mu \mathrm{m}, I=200 \mathrm{~cm}$, flow rate of a solution of an electrophile: $4.00 \mathrm{~mL} \cdot \mathrm{min}^{-1}$. ${ }^{\mathrm{f}}$ 2-Bromo-7-butyl-9,9-dioctylfluorene (31) was also produced as a byproduct. ${ }^{g}$ Isolated yield. 


\section{Synthesis of Unsymmetrically Substituted} Biaryls from 4,4'-Dibromobiphenyl (17) by Sequential Introduction of Two Electrophiles

With successful monolithiation of 4,4'-dibromobiphenyl (17) followed by the reaction with an electrophile using the microflow system in hand, sequential introduction of two electrophiles ( $\mathrm{E}^{1}$ and $\mathrm{E}^{2}$ ) onto 4,4'-dibromobiphenyl (17) was carried out using an integrated microflow system composed of four T-shaped micromixers and four microtube reactors shown in Figure 3. As summarized in Table 7, the sequential introductions of two electrophiles were achieved successfully without isolation of a monobromo biaryl compound.

\section{Br-Li Exchange Reaction of Other Dibromobi- aryls and 2,2'-Dibromobibenzyl (43)}

We next examined the reactions of other dibromobiaryls such as 2,7-dibromo-9,9-dioctylfluorene (28), and 2,2'-dibromo-1,1'binaphthyl (36) [58] using the microflow system. As summarized in Table 8 , monolithiation was achieved with high selectivity even at $0{ }^{\circ} \mathrm{C}$ and $24{ }^{\circ} \mathrm{C}$. Such high selectivity is difficult to obtain with macrobatch reactors at similar temperatures such as $0{ }^{\circ} \mathrm{C}$. It is also noteworthy that monolithiation of 2,2' dibromobibenzyl (43) can be achieved with high selectivity even at $0{ }^{\circ} \mathrm{C}$ and $24{ }^{\circ} \mathrm{C}$. The resulting organolithium interme- diate reacted with various electrophiles to give the corresponding products in high yields with high selectivity.

\section{Synthesis of Unsymmetrically Substituted Biaryls by Sequential Introduction of Two Electrophiles}

With successful monolithiation of dibromobiaryls such as 2,7dibromo-9,9-dioctylfluorene (28) and 2,2'-dibromobinaphthyl (36) followed by the reaction with an electrophile using the microflow system in hand, sequential introduction of two electrophiles $\left(\mathrm{E}^{1}\right.$ and $\mathrm{E}^{2}$ ) onto dibromobiaryls was carried out using an integrated microflow system composed of four T-shaped micromixers and four microtube reactors shown in Figure 3.

As summarized in Table 9, the sequential introductions of two electrophiles were achieved successfully with various combinations of electrophiles without isolation of monobromo biaryl compounds. This integrated microflow synthesis serves as a straightforward and powerful method for synthesizing unsymmetrically substituted biaryls from dibromobiaryls and two electrophiles.

In conclusion, we have developed an efficient method for selective monolithiation of dibromobiaryls at $0{ }^{\circ} \mathrm{C}$ by virtue of

Table 9: Synthesis of unsymmetrially substituted biaryls from dibromobiaryls by sequential introduction of two electrophiles. ${ }^{a}$

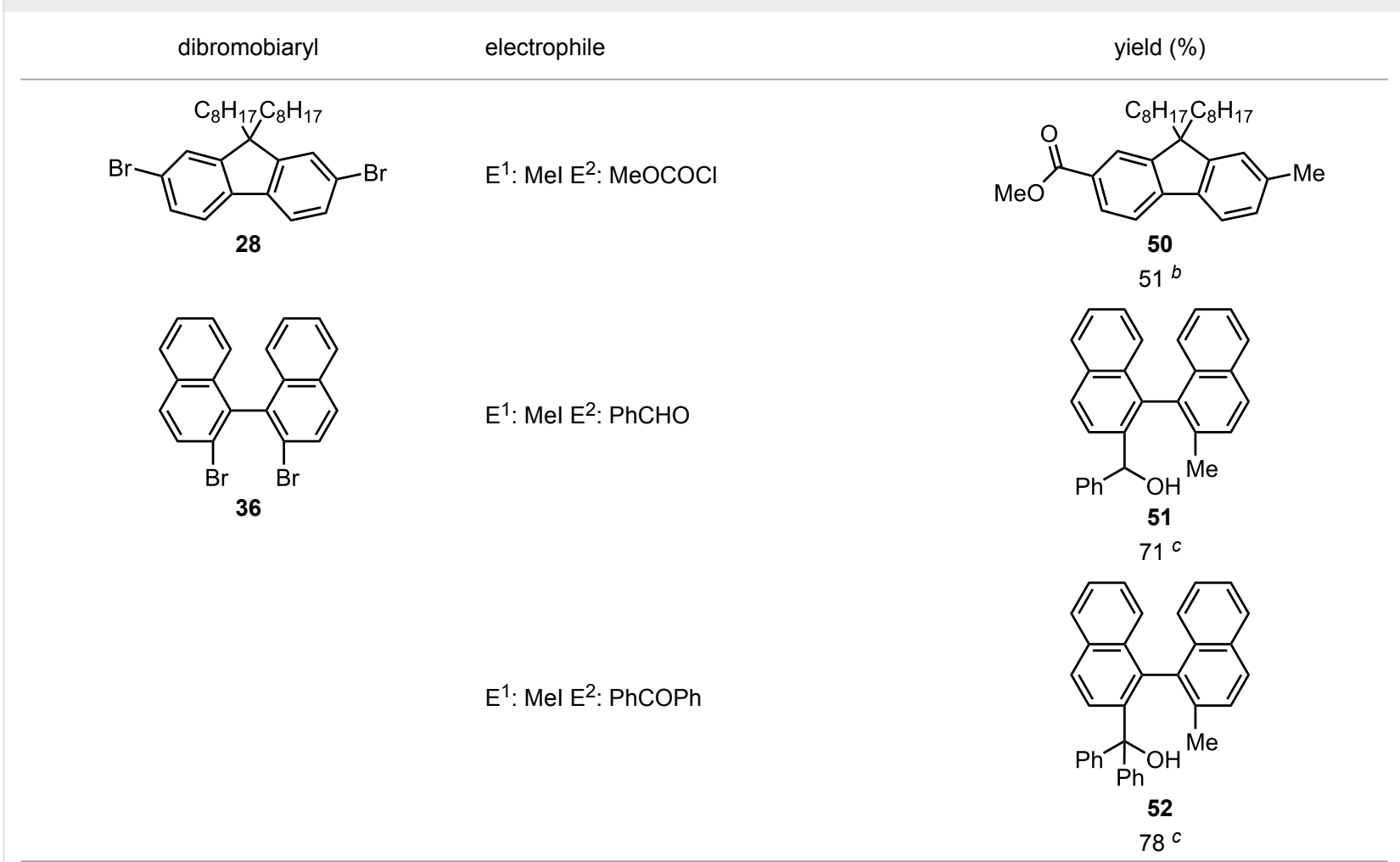

${ }^{a}$ Reactions were conducted in the microflow system shown in Figure 3 unless otherwise stated. ${ }^{b}$ Determined by GC. ${ }^{c}$ Isolated yield. 
fast mixing in microflow systems. Electrophiles was introduced on one of the aromatic rings with high selectivity. Sequential introduction of two electrophiles by repeating the sequence have also been achieved using the integrated microflow systems. Unsymmetrically substituted biaryls were obtained in high selectivity. The results obtained in this study speak well for the potential of integrated microflow systems in multi-step synthesis in flash chemistry [59-61], and the method adds a new dimension to the synthesis of unsymmetrically substituted biaryls.

\section{Supporting Information}

Experimental procedures and full spectroscopic data for all new compounds are provided as supporting information.

\section{Supporting Information File 1}

Experimental procedures for compounds 1-52.

[http://www.beilstein-journals.org/bjoc/content/ supplementary/1860-5397-5-16-S1.pdf]

\section{Supporting Information File 2}

${ }^{1} \mathrm{H}$ NMR spectra and ${ }^{13} \mathrm{C}$ NMR spectra of compounds $4, \mathbf{5}$, 9-16, 19, 22-26, 31-35, 39.

[http://www.beilstein-journals.org/bjoc/content/ supplementary/1860-5397-5-16-S2.pdf]

\section{Supporting Information File 3}

${ }^{1} \mathrm{H}$ NMR spectra and ${ }^{13} \mathrm{C}$ NMR spectra of compounds $\mathbf{4 1}$, 42, 46, 48-52.

[http://www.beilstein-journals.org/bjoc/content/ supplementary/1860-5397-5-16-S3.pdf]

\section{Acknowledgments}

This work was financially supported in part by a Grant-in-Aid for Scientific Research from the Japan Society for the Promotion of Science and NEDO projects.

\section{References}

1. Cepanec, I. Synthesis of Biaryls; ELSEVIER, 2004.

2. Negishi, E. Handbook of Organopalladium Chemistry for Organic Synthesis; Wiley-Interscience: New York, 2002.

3. Lloyd-Jones, G. C. Angew. Chem., Int. Ed. 2002, 41, 953-956. doi:10.1002/1521-3773(20020315)41:6<953::AID-ANIE953>3.0.CO;29

4. Culkin, D. A.; Hartwig, J. F. Acc. Chem. Res. 2003, 36, 234-245. doi:10.1021/ar0201106

5. Tietze, L. F.; lla, H.; Bell, H. P. Chem. Rev. 2004, 104, 3453-3516. doi:10.1021/cr030700x

6. Cacchi, S.; Fabrizi, G. Chem. Rev. 2005, 105, 2873-2920. doi:10.1021/cr040639b
7. Christmann, U.; Vilar, R. Angew. Chem., Int. Ed. 2005, 44, 366-374. doi:10.1002/anie.200461189

8. Liebscher, J.; Yin, L. Chem. Rev. 2007, 107, 133-173. doi:10.1021/cr0505674

9. Doucet, H.; Hierso, J. C. Angew. Chem., Int. Ed. 2007, 46, 834-871. doi:10.1002/anie.200602761

10. Beak, P.; Liu, C. Tetrahedron Lett. 1994, 20, 5999-6004.

11. Dolman, S. J.; Gosselin, F.; O'Shea, P. D.; Davies, I. W. Tetrahedron 2006, 62, 5092-5098. doi:10.1016/j.tet.2006.03.039

12. Kliś, T.; Servatowski, J. Tetrahedron Lett. 2007, 48, 1169-1173. doi:10.1016/j.tetlet.2006.12.076

13. Fletcher, P. D. I.; Haswell, S. J.; Pombo-Villar, E.; Warrington, B. H.; Watts, P.; Wong, S. Y. F.; Zhang, X. Tetrahedron 2002, 58, 4735-4757. doi:10.1016/S0040-4020(02)00432-5

14. Jähnisch, K.; Hessel, V.; Löwe, H.; Baerns, M. Angew. Chem., Int. Ed. 2004, 43, 406-446. doi:10.1002/anie.200300577

15. Doku, G. N.; Verboom, W.; Reinhoudt, D. N.; van den Berg, A. Tetrahedron 2005, 61, 2733-2742. doi:10.1016/j.tet.2005.01.028

16. Fukuyama, T.; Shinmen, M.; Nishitani, S.; Sato, M.; Ryu, I. Org. Lett. 2002, 4, 1691-1694. doi:10.1021/ol0257732

17. Kobayashi, J.; Mori, Y.; Okamoto, K.; Akiyama, R.; Ueno, M.; Kitamori, T.; Kobayashi, S. Science 2004, 304, 1305-1308. doi:10.1126/science.1096956

18. Wu, T.; Mei, Y.; Cabrai, J. T.; Xu, C.; Beers, K. L. J. Am. Chem. Soc. 2004, 126, 9880-9881. doi:10.1021/ja048432n

19. Ducry, L.; Roberge, D. M. Angew. Chem., Int. Ed. 2005, 44, 7972-7975. doi:10.1002/anie.200502387

20. Iwasaki, T.; Yoshida, J. Macromolecules 2005, 38, 1159-1163. doi:10.1021/ma048369m

21. Lee, C. C.; Sui, G. D.; Elizarov, A.; Shu, C. Y. J.; Shin, Y. S.; Dooley, A. N.; Huang, J.; Daridon, A.; Wyatt, P.; Stout, D.; Kolb, H. C.; Witte, O. N.; Satyamurthy, N.; Heath, J. R.; Phelps, M. E.; Quake, S. R.; Tseng, H. R. Science 2005, 310, 1793-1796. doi:10.1126/science.1118919

22. He, P.; Watts, P.; Marken, F.; Haswell, S. J. Angew. Chem., Int. Ed. 2006, 45, 4146-4149. doi:10.1002/anie.200600951

23. Uozumi, Y.; Yamada, Y.; Beppu, T.; Fukuyama, N.; Ueno, M.; Kitamori, T. J. Am. Chem. Soc. 2006, 128, 15994-15995. doi:10.1021/ja066697r

24. Belder, D.; Ludwig, M.; Wang, L. W.; Reetz, M. T. Angew. Chem., Int. Ed. 2006, 45, 2463-2466. doi:10.1002/anie.200504205

25. Tanaka, K.; Motomatsu, S.; Koyama, K.; Tanaka, S.; Fukase, K. Org. Lett. 2007, 9, 299-302. doi:10.1021/ol062777o

26. Sahoo, H. R.; Kralj, J. G.; Jensen, K. F. Angew. Chem., Int. Ed. 2007, 46, 5704-5708. doi:10.1002/anie.200701434

27. Rys, P. Acc. Chem. Res. 1976, 10, 345-351. doi:10.1021/ar50106a001

28. Rys, P. Angew. Chem., Int. Ed. 1977, 12, 807-817. doi:10.1002/anie.197708073

29. Suga, S.; Nagaki, A.; Yoshida, J. Chem. Commun. 2003, 354-355. doi:10.1039/b211433j

30. Suga, S.; Nagaki, A.; Tsutsui, Y.; Yoshida, J. Org. Lett. 2003, 5, 945-948. doi:10.1021/ol0341243

31. Suga, S.; Tsutsui, Y.; Nagaki, A.; Yoshida, J. Bull. Chem. Soc. Jpn. 2005, 78, 1206-1217. doi:10.1246/bcsj.78.1206

32. Nagaki, A.; Togai, M.; Suga, S.; Aoki, N.; Mae, K.; Yoshida, J. J. Am. Chem. Soc. 2005, 127, 11666-11675. doi:10.1021/ja0527424

33. Yoshida, J.; Nagaki, A.; Iwasaki, T.; Suga, S. Chem. Eng. Technol. 2005, 28, 259-266. doi:10.1002/ceat.200407127 
34. Kawaguchi, T.; Miyata, H.; Ataka, K.; Mae, K.; Yoshida, J. Angew. Chem., Int. Ed. 2005, 44, 2413-2416. doi:10.1002/anie.200462466

35. Nagaki, A.; Kawamura, K.; Suga, S.; Ando, T.; Sawamoto, M.; Yoshida, J. J. Am. Chem. Soc. 2004, 126, 14702-14703. doi:10.1021/ja044879k

36. Iwasaki, T.; Nagaki, A.; Yoshida, J. Chem. Commun. 2007, 1263-1265. doi:10.1039/b615159k

37. Nagaki, A.; Iwasaki, T.; Kawamura, K.; Yamada, D.; Suga, S.; Ando, T.; Sawamoto, M.; Yoshida, J. Chem.-Asian J. 2008, 3, 1558-1567. doi:10.1002/asia.200800081

38. Nagaki, A.; Tomida, Y.; Yoshida, J. Macromolecules 2008, 41, 6322-6330. doi:10.1021/ma800769n

39. Nagaki, A.; Kim, H.; Yoshida, J. Angew. Chem., Int. Ed. 2008, 47, 7833-7836. doi:10.1002/anie.200803205

40. Nagaki, A.; Takizawa, E.; Yoshida, J. J. Am. Chem. Soc. 2009, 131 , 1654-1655. doi:10.1021/ja809325a

(See also: Nagaki, A.; Takizawa, E.; Yoshida, J. J. Am. Chem. Soc. 2009, 131, 3787. doi:10.21/ja9008979).

41. Karnatz, F. A.; Whitmore, F. C. J. Am. Chem. Soc. 1932, 54, 3461. doi:10.1021/ja01347a509

42. Skelton, V.; Greenway, G. M.; Haswell, S. J.; Styring, P.; Morgan, D. O.; Warrington, B. H.; Wong, S. Y. F. Analyst 2001, 126, 11-13. doi:10.1039/b006727j

43. Reetz, M. T.; Wiesenhofer, W.; Francio, G.; Leitner, W. Adv. Synth. Catal. 2003, 345, 1221-1228. doi:10.1002/adsc.200303109

44. Wiles, C.; Watts, P.; Haswell, S. J.; Pombo-Villar, E. Tetrahedron 2003, 59, 10173-10179. doi:10.1016/j.tet.2003.10.069

45. Jas, G.; Kirschning, A. Chem.-Eur. J. 2003, 9, 5708-5723. doi:10.1002/chem.200305212

46. Miller, P. W.; Long, N. J.; Mello, A. J.; Vilar, R.; Passchier, J.; Gee, A. Chem. Commun. 2006, 546-548. doi:10.1039/b515710b

47. Shore, G.; Morin, S.; Organ, M. G. Angew. Chem., Int. Ed. 2006, 45, 2761-2766. doi:10.1002/anie.200503600

48. Bonfils, F.; Cazaux, I.; Hodge, P.; Caze, C. Org. Biomol. Chem. 2006, 4, 493-497. doi:10.1039/b515241k

49. Baxendale, I. R.; Deeley, J.; Ley, S. V.; Griffiths-Jones, C. H.; Saaby, S.; Tranmer, G. K. Chem. Commun. 2006, 2566-2568. doi:10.1039/b600382f

50. Baxendale, I. R.; Griffiths-Jones, C. H.; Ley, S. V.; Tranmer, G. K. Synlett 2006, 427-430.

51. Baxendale, I. R.; Griffiths-Jones, C. H.; Ley, S. V.; Tranmer, G. K. Chem.-Eur. J. 2006, 12, 4407-4416. doi:10.1002/chem.200501400

52. Usutani, H.; Tomida, Y.; Nagaki, A.; Okamoto, H.; Nokami, T.; Yoshida, J. J. Am. Chem. Soc. 2007, 129, 3046-3048. doi:10.1021/ja068330s

53. Nagaki, A.; Tomida, Y.; Usutani, H.; Kim, H.; Takabayashi, N.; Nokami, T.; Okamoto, H.; Yoshida, J. Chem.-Asian J. 2007, 2, 1513-1523. doi:10.1002/asia.200700231

54. Nagaki, A.; Takabayashi, N.; Tomida, Y.; Yoshida, J. Org. Lett. 2008, 18, 3937-3940. doi:10.1021/ol8015572

55. Leroux, F.; Nicod, N.; Bonnafoux, L.; Quissac, B.; Colobert, F. Lett. Org. Chem. 2006, 3, 165-169.

56. Morrison, D. J.; Trefz, T. K.; Piers, W. E.; McDonald, R.; Parvez, M. J. Org. Chem. 2005, 70, 5309-5312. doi:10.1021/jo0506231

57. Ehrfeld, W.; Golbig, K.; Hessel, V.; Löwe, H.; Richter, T. Ind. Eng. Chem. Res. 1999, 38, 1075-1082. doi:10.1021/ie980128d

58. Hoshi, T.; Hayakawa, T.; Suzuki, T.; Hagiwara, H. J. Org. Chem. 2005, 70, 9085-9087. doi:10.1021/jo051581j
59. Yoshida, J. Flash Chemistry. Fast Organic Synthesis in Microsystems; Wiley-Blackwell, 2008.

60. Yoshida, J.; Nagaki, A.; Yamada, T. Chem.-Eur. J. 2008, 14, 7450-7459. doi:10.1002/chem.200800582

61. Yoshida, J. Chem. Commun. 2005, 4509-4516. doi:10.1039/b508341a

\section{License and Terms}

This is an Open Access article under the terms of the Creative Commons Attribution License

(http://creativecommons.org/licenses/by/2.0), which permits unrestricted use, distribution, and reproduction in any medium, provided the original work is properly cited.

The license is subject to the Beilstein Journal of Organic Chemistry terms and conditions:

(http://www.beilstein-journals.org/bjoc)

The definitive version of this article is the electronic one which can be found at: doi:10.3762/bjoc.5.16 